
\title{
Reserarch Suare \\ Detection of Suspended SARS-CoV-2 in Indoor Air Using an Electrostatic Sampler
}

Kyohei Fukuda ( $\nabla$ kyohei_fukuda@amano.co.jp )

AMANO Co., Ltd

Mie Yoshida

AMANO Co., Ltd

Kensuke Noto

AMANO Co., Ltd

Kouichi Kitabayashi

AMANO Co., Ltd

Shinjirou Katsushima

AMANO Co., Ltd

Hiroki Sonehara

Genome Clinic Co.,Ltd

Kazue Mizuno

MRC LLC

Akira Mizuno

AMANO Co., Ltd

\section{Research Article}

Keywords: prototype virus sampler, SARS-CoV-2, indoor air, an electrostatic sampler

Posted Date: January 12th, 2022

DOI: https://doi.org/10.21203/rs.3.rs-1236810/v1

License: (c) (i) This work is licensed under a Creative Commons Attribution 4.0 International License.

Read Full License 


\section{Abstract}

A prototype virus sampler using electrostatic precipitation has been developed to investigate aerosol infection by SARS-CoV-2. The sampler consists of a discharge electrode placed inside a vial, and a thin layer of viral lysis buffer at the bottom, working as a collection electrode. The sampler was operated with the sampling air flow rate of $40 \mathrm{~L} / \mathrm{min}$. Collection efficiency of the sampler is about $80 \%$ for $25 \mathrm{~nm}$ to $5.0 \mu \mathrm{m}$ diameter particles. We sampled the air of a food court of a commercial facility, a connecting corridor of a clouded train station, and two office rooms (A and B) in September 2021, just after the $5^{\text {th }}$ peak of COVID-19 in Japan. The analysis using a RT-qPCR detected the virus RNA in the air of the office A, $B$ and the food court. Estimated concentration of the virus in the air determined by calibration curve was $2.0 \times 10^{2}, 7.8 \times 10^{2}$, and $0.6-2.4 \times 10^{2} \mathrm{copies} / \mathrm{m}^{3}$, in the office $A, B$, and the food court, respectively. These results indicate that the sampler using electrostatic precipitation can detect SARS-CoV-2 in indoor air. It could be developed as a risk assessment method for aerosol infection.

\section{Introduction}

Although droplet and contact infections have been thought to be the main routes of SARS-CoV-2 transmission, aerosol infections have also been found to be an important route $\mathrm{e}^{1,2,3,4,5}$. The Centers for Disease Control and Prevention report in May 2021 also pointed out the aerosol transmission ${ }^{6}$. Aerosols are particles emitted by coughing, sneezing, or breathing, then drying up in the air to become smaller and floating for long time. To prevent aerosol infection, ventilation (complete air exchange) is recommended. However, in many commercial facilities and restaurants, it is difficult to provide sufficient ventilation due to weather conditions and structural problem. Monitoring SARS-CoV-2 floating in indoor air is important to know the degree of contamination for countermeasures against aerosol infection. To date, airborne sampling results have been reported from medical facilities where patients with SARS-CoV-2 are admitted $^{7,8}$. In addition, there are examples of measurements in general environments such as commercial facilities, offices, and buses $^{9}$, but due to the limitations of the samplers, long sampling times are required. Midget impingers and gelatin filters are commonly used as bioaerosol samplers ${ }^{10,11}$. The gelatin filter requires elution of the collected virus, and the midget impinger has low collection efficiency. Recently, samplers using electrostatic precipitator ${ }^{12}$ have been reported ${ }^{13,14,15,16}$. Electrostatic precipitator has advantages such as low pressure drop, high collection efficiency for fine particles, and collection on liquid, and can be designed to suit the application.

We have developed a prototype sampler that incorporates electrostatic precipitation into a vial and collects the particles in a liquid. Using a viral lysis buffer as the collection electrode, we were able to reduce the risk of infection to workers. Using the prototype electrostatic sampler, sampling was conducted in the third week of September 2021, just after the peak of the fifth wave of COVID-19 in Japan, at a food court in a commercial facility, a station passageway, and two office locations (A and B). The virus RNA was detected in the air of the food court and the two offices. 


\section{Results And Discussion}

\section{Collection efficiency of the electrostatic samplers}

Collection efficiency of the electrostatic sampler was measured using a Fast Mobility Particle Sizer for particles less than $0.3 \mu \mathrm{m}$ in diameter and an optical particle counter for particles larger than $0.3 \mu \mathrm{m}$. The sample gas of incense smoke diluted with air was used to contain a wide range of particles from $5.6 \mathrm{~nm}$ to $5.0 \mu \mathrm{m}$, with the most frequent particle size being $60 \mathrm{~nm}$. The collection efficiency of the sampler was $88 \%$ at $25 \mathrm{~nm}, 81 \%$ at $50 \mathrm{~nm}, 81 \%$ at $100 \mathrm{~nm}, 83 \%$ at $200 \mathrm{~nm}, 80 \%$ at $300 \mathrm{~nm}, 87 \%$ at $500 \mathrm{~nm}$, and $100 \%$ at $5 \mu \mathrm{m}$.

\section{Possible damage to nucleic acids by corona discharge}

Corona discharges produce reactive species such as $\mathrm{NO}$ and $\mathrm{O}$. These reactive species can denature the nucleic acids in the collected microorganisms and viruses $17,18,19,20$ and affect the analysis of PCR. To confirm the effect on nucleic acids, bacteriophage MS2 was added to the AVL buffer, then, exposed to the discharge, and analyzed using RT-qPCR. The comparison was made using the same condition of the discharge and the buffer for conducting the sampling. Figure 1 shows the results. Each test was performed twice. Bacteriophage MS2 exposed to the discharge for 90 min. was detected at 21.89 and 22.19 cycles by the PCR, while untreated bacteriophage MS2 was detected at 22.46 and 22.40 cycles. These results indicate that the effect of the exposure to the discharge on detection of RNA of collected MS2 by running the sampler for 90 minutes is negligible.

\section{Sampling of indoor air}

The sampling was conducted at a food court of a commercial facility, a passage of a clouded train station, and two different offices (A and B) in the third week of September 2021, just after the peak of the fifth wave of COVID-19 in Japan. The sampled specimens were analyzed by RT-qPCR. Figure 2a shows the amplification curve of the RT-qPCR targeting the N2 region, and Figure $2 \mathrm{~b}$ shows the calibration curve using the step dilution series of the positive control of the $\mathrm{N} 2$ region. The results are summarized in Table 1. In the office $A$, the virus RNA was detected in all amplified regions. In the office $B$, the virus was detected in two different amplified regions. In the food court of a commercial facility, the detection was made in one of two conditions. In the connecting passage of the train station, the virus was not detected. In the station, everyone wore masks and moved in silence, therefore, aerosol was not generated easily. On the other hand, in food courts and offices, most of the people did not wear masks, and generation of aerosol from human was easily took place.

The concentration of the virus was calculated based on the calibration curve in the N2 region of the realtime PCR. The office B had the highest airborne concentration of $7.8 \times 10^{2} \mathrm{copies} / \mathrm{m}^{3}$, followed by Office A with $2.0 \times 10^{2}$ copies $/ \mathrm{m}^{3}$, and the food court with $0.6-1.9 \times 10^{2} \mathrm{copies} / \mathrm{m}^{3}$. These concentrations are 
higher than the results from the hospital shown in the literature ${ }^{9}$. Concentration measurements from the number of PCR cycles are not very accurate, and possibly these values are not reliable. Or, possibly infected persons were present at the time of sampling.

Table 1

RT-qPCR detection results of SARS-CoV-2 in indoor environment and suspended concentrations calculated from the calibration curve.

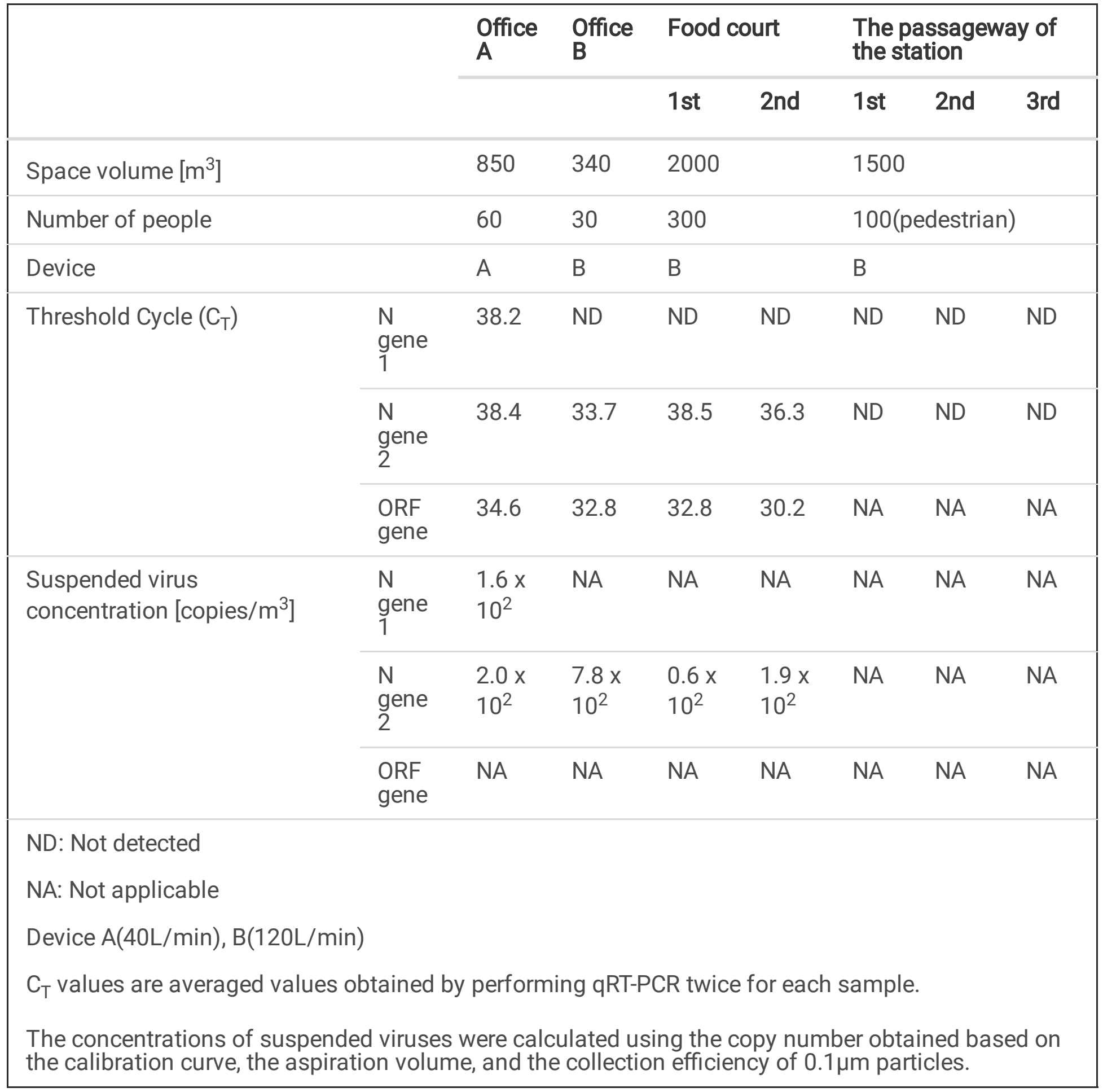

\section{Conclusions}


The indoor air was sampled using a prototype electrostatic sampler. As a result, the following conclusions were obtained

(1) The collection efficiency of the sampler was about $80 \%$ for particles from $25 \mathrm{~nm}$ to $5.0 \mu \mathrm{m}$ under the conditions of $-6 \mathrm{kV},-80 \mu \mathrm{A}$, and sampling air flow rate of $40 \mathrm{~L} / \mathrm{min}$.

(2) Bacteriophage MS2 in Buffer AVL was exposed to the discharge for 1.5 hours under the same conditions as the sampling, and the effect of discharge on the detection by RT-PCR was proved to be negligible.

(3) In a food court, and office, SARS-CoV-2 RNA floating in the air was detected using the electrostatic sampler and RT-qPCR.

Air sampling using electrostatic precipitation could be developed as a risk assessment method for aerosol infection.

\section{Methods}

\section{Structure of the electrostatic samplers}

Electrostatic precipitation is a method of charging and collecting suspended particles by corona discharge. The smaller the radius of curvature of an electrode, the lower the voltage required to generate corona discharge. A bundle of 100 metallic fibers with $12 \mu \mathrm{m}$ diameter was used as the discharge electrode $^{21}$. About $2 \mathrm{~mL}$ of Buffer AVL (QIAGEN, Germany) supplied in the vial, which was used as the collection electrode. The buffer is a viral lysis solution used for purifying viral nucleic acids. Using the buffer as the collection electrode, we were able to reduce the risk of infection to workers. Figure 3 shows the schematic diagram of the sampler. A metal tube with $20 \mathrm{~mm}$ diameter was inserted into the center of a vial with $40 \mathrm{~mm}$ diameter. 11 bundles for corona discharge were attached to the tip of the tube. The gap between the discharge electrode and the surface of the buffer AVL was $\square x e d$ to $10 \mathrm{~mm}$. The applied voltage was $\mathrm{DC}-6 \mathrm{kV}$ and the discharge current was $-80 \mu \mathrm{A}$. The sampling air flow rate was $40 \mathrm{~L} / \mathrm{min}$. The air flowing in from the central metal tube was turned back in the vial and exhausted to the surrounding area. Meanwhile, the charged aerosol is collected into the buffer by electrostatic force.

\section{Collection efficiency of the electrostatic samplers}

Incense smoke was mixed with air to form sample gas and used in a room with a volume of $100 \mathrm{~m}^{3}$. This was conducted to increase the number of airborne particles with $300 \mathrm{~nm}$ to $5000 \mathrm{~nm}$ of diameter in the indoor air. The sample gas was passed through the electrostatic sampler to measure the collection efficiency. A Fast Mobility Particle Sizer (FMPS; TSI, USA) and an optical particle counter Model 3888 (Kanomax, Japan) were used. FMPS can measure particles from $5.6 \mathrm{~nm}$ to $560 \mathrm{~nm}$, and the particle 
counter can measure particles from $0.3 \mu \mathrm{m}$ to $5.0 \mu \mathrm{m}$. The collection efficiency was calculated using the ratio of particle-count with the high voltage (HV) turned ON and OFF.

\section{Possibility of damage to nucleic acids by corona discharge}

To confirm the effect on nucleic acids, bacteriophage MS2 was exposed to the discharge, and analyzed using RT-qPCR. Bacteriophage MS2 (NBRC 102619) and Escherichia coli (NBRC 13965) were mixed and incubated overnight at $35^{\circ} \mathrm{C}$ in liquid LB medium. $4 \mathrm{~mL}$ of SM buffer and $40 \mu \mathrm{L}$ of chloroform were added into the mixture and allowed to stand at room temperature for 30 minutes. The mixture was filtered through a syringe filter with a pore size of $0.22 \mu \mathrm{m}$. Bacteriophage MS2 suspension with concentration of $5 \times 10^{7} \mathrm{PFU} / \mu \mathrm{L}$ was obtained.

$1 \mu \mathrm{L}$ of bacteriophage MS2 suspension was added to $2.9 \mathrm{~mL}$ of solution $(1.12 \mathrm{~mL}$ of Buffer $\mathrm{AVL}$ and 1.78 $\mathrm{mL}$ of DW, DW: deionized water). DW was added to prevent salt deposition caused by evaporation. The solution was supplied in a vial and was used as the collection electrode. Samples were prepared by applying corona discharge and air flow or air flow only for $90 \mathrm{~min}$.

\section{Bacteriophage MS2 RNA extraction and RT-qPCR detection}

RNA was extracted from each sample using the QIAamp Viral RNA mini kit (QIAGEN, Germany) following the protocol. The presence of bacteriophage MS2 RNA was detected using One Step Prime Script III RTqPCR Mix (TAKARA BIO, Japan) and primer-probe sets targeting of the coat protein. The sequences of the primers and probe are 5'-CGTTCACAGGCTTACAAAGTAACCT-3', 5'-CCAACAGTCTGGGTTGCCAC-3', and FAT-AGAATCGCAAATACACCATCAAAGTCGAGGT-TAMRA, respectively ${ }^{22}$. Reaction mixtures contained 10 $\mu \mathrm{L}$ of One Step Prime Script III RT-qPCR Mix, $1 \mu \mathrm{L}$ of each $0.5 \mu \mathrm{M}$ primer, $1 \mu \mathrm{L}$ of $0.5 \mu \mathrm{M}$ probe, $6.0 \mu \mathrm{L}$ of RNase Free $\mathrm{H}_{2} \mathrm{O}$, and $1 \mu \mathrm{L}$ of extracted RNA. The PCR conditions were $52^{\circ} \mathrm{C}$ for $5 \mathrm{~min}, 95^{\circ} \mathrm{C}$ for $10 \mathrm{sec}$ and 45 cycles of $95^{\circ} \mathrm{C}$ for $10 \mathrm{sec}$ and $60^{\circ} \mathrm{C}$ for $30 \mathrm{sec}$. The PCR device was used Mygo Mini S Real Time PCR (IT-IS Life Science, UK).

\section{Sampling of indoor air}

The sampling was conducted at a food court of a commercial facility, a passage of a clouded train station, and two different offices ( $A$ and B). The food court of the commercial facility was about $2000 \mathrm{~m}^{3}$ in size, and about 300 people were eating and talking without masks. The passage of the clouded train station was about $1500 \mathrm{~m}^{3}$ in size, and about 100 people were walking through it at any given time. Office A was $850 \mathrm{~m}^{3}$ in size, and there were 60 people in the room. Office B was $340 \mathrm{~m}^{3}$ in size, and there were 30 people in the room. 
Two types of prototype devices ( $A$ and $B$ ) were used in the demonstration test. Device A consists of one sampler with the sampling air flow rate of $40 \mathrm{~L} / \mathrm{min}$, and device $B$ consists of three samplers in parallel with the sampling air flow rate of $120 \mathrm{~L} / \mathrm{min}$. The size of both devices was $300 \mathrm{~mm}$ (length), $300 \mathrm{~mm}$ (width), and $150 \mathrm{~mm}$ (height), and they were powered by a battery with $12 \mathrm{~V}$ output. The buffers for each sampler were $2.9 \mathrm{~mL}$ ( $1.12 \mathrm{~mL}$ of Buffer AVL and $1.78 \mathrm{~mL}$ of DW). DW was added to prevent salt deposition caused by evaporation. Sampling time was 90 minutes. The volume of solution after sampling was $1.4 \mathrm{~mL}$ for device $A$ and $4.2 \mathrm{~mL}(1.4 \mathrm{~mL} \times 3)$ for device $B$.

\section{Viral RNA extraction and RT-qPCR detection}

RNA was extracted from each sample using the QIAamp Viral RNA mini kit (QIAGEN, Germany) following the protocol. The extracted solution was $60 \mu \mathrm{L}$. The presence of SARS-CoV-2 RNA was detected targeting the $\mathrm{N}$ and open reading frame (ORF) gene regions.

In the N region, the kit used for detection is One Step Prime Script III RT-qPCR Mix (TAKARA BIO, Japan), Primer/Probe Set (TAKARA BIO, Japan), and Positive Control RNA Mix (2019-nCov) as positive control. Reaction mixtures of $\mathrm{N} 1$ set contained $10 \mu \mathrm{L}$ of One Step Prime Script III RT-qPCR Mix, $4.0 \mu \mathrm{L}$ of $5 \mathrm{x}$ N_Sarbeco_Primer/Probe mix, $1.0 \mu \mathrm{L}$ of RNase Free $\mathrm{H}_{2} \mathrm{O}$, and $5 \mu \mathrm{L}$ of extracted RNA. Total volume is 20 $\mu \mathrm{L}$. Reaction mixtures of $\mathrm{N} 2$ set contained $10 \mu \mathrm{L}$ of One Step Prime Script III RT-qPCR Mix, $4.0 \mu \mathrm{L}$ of $5 \mathrm{x}$ NIID_2019_nCOV_N_Primer/Prove mix, $1.0 \mu \mathrm{L}$ of RNase Free $\mathrm{H}_{2} \mathrm{O}$, and $5 \mu \mathrm{L}$ of extracted RNA. Total volume is $20 \mu \mathrm{L}$. The PCR conditions were $52^{\circ} \mathrm{C}$ for $5 \mathrm{~min}, 95^{\circ} \mathrm{C}$ for $10 \mathrm{sec}$ and 45 cycles of $95^{\circ} \mathrm{C}$ for 10 sec and $60^{\circ} \mathrm{C}$ for $30 \mathrm{~s}$. The PCR device was used Mygo Mini S Real Time PCR (IT-IS Life Science).

In the ORF region, the kit used for detection is 2019-nCoV Detection Fluorescence RT-qPCR Kit (Sysmex, Japan). Reaction mixtures contained $18.5 \mu \mathrm{L}$ of 2019-nCoV Reaction Mix, $1.5 \mu \mathrm{L}$ of 2019-nCoV Enzyme Mix and $10 \mu \mathrm{L}$ of extracted RNA. Total volume is $20 \mu \mathrm{L}$. The PCR conditions were $50^{\circ} \mathrm{C}$ for $20 \mathrm{~min}, 95^{\circ} \mathrm{C}$ for $10 \mathrm{~min}$ and $45 \mathrm{cycles}$ of $95^{\circ} \mathrm{C}$ for $15 \mathrm{sec}$ and $60^{\circ} \mathrm{C}$ for $30 \mathrm{sec}$. The PCR device is the same as above.

A calibration curve was prepared using the positive control for the $\mathrm{N}$ region. For the ORF region, a calibration curve could not be drawn due to the low concentration of the commercial positive control. The positive control was adjusted by 10 -fold dilution from $1.0 \times 10^{0}$ to $1.0 \times 10^{3} \mathrm{copies} / \mu \mathrm{L}$, and calibration curves were drawn for the $\mathrm{N} 1$ and $\mathrm{N} 2$ regions using the PCR conditions described above. The RT-qPCR data were quantitatively analyzed using the calibration curve and the suspended concentration per $1 \mathrm{~m}^{3}$ of aspirated air was calculated.

\section{Declarations}

\section{Author contributions statement}

K.F., K.K., S.K., K.M. and A.M. conceived and designed the experiment devices. K.F. and M.Y. evaluated the performance of the device. K.F., M.Y. and K.N. conducted the demonstration tests. H.S. performed RT- 
qPCR analysis. K.F. and A.M. prepared the manuscript. All authors discussed the results and edited the manuscript.

\section{Additional information}

We know of no conflicts of interest associated with this publication, and there has been no significant financial support for this work that could have influenced its outcome.

\section{References}

1. Alsved, M. et al. Exhaled respiratory particles during singing and talking. Aerosol Science and Technology. 54, 1245-1248 (2020).

2. Cai , J. et al. Indirect Virus Transmission in Cluster of COVID-19 Cases, Wenzhou, China, 2020. Emerging Infectious Disease journal. 26, 1343 (2020).

3. Lu, J. et al. COVID-19 Outbreak Associated with Air Conditioning in Restaurant, Guangzhou, China, 2020. Emerging Infectious Disease journal. 26, 1628 (2020).

4. Klompas, M. et al. A SARS-CoV-2 Cluster in an Acute Care Hospital. Ann Intern Med. 174, 794-802 (2021).

5. Tang, J. W., Marr, L. C., Li, Y. and Dancer, S. J. Covid-19 has redefined airborne transmission. BMJ. 373, n913 (2021).

6. Centers for Disease Control and Prevention, Scientific Brief: SARS-CoV-2 Transmission: SARS-CoV-2 is transmitted by exposure to infectious respiratory fluids. https://www.cdc.gov/coronavirus/2019ncov/science/science-briefs/sars-cov-2-transmission.html (2021).

7. Mizukoshi, A., Nakama, C., Okumura, J. and Azuma, K. Assessing the risk of COVID-19 from multiple pathways of exposure to SARS-CoV-2: Modeling in health-care settings and effectiveness of nonpharmaceutical interventions. Environment International. 147, 106338 (2021).

8. Liu, Y. et al. Aerodynamic analysis of SARS-CoV-2 in two Wuhan hospitals. Nature. 582, 557-560 (2020).

9. Carlo, P. D. et al. Air and surface measurements of SARS-CoV-2 inside a bus during normal operation. PLOS ONE. 15, e0235943 (2020).

10. Nakanishi, A. et al. Evaluation Method on Removability of Airborne Virus - Evaluation Method Using Bacteriophage $\varphi$ X 174. J. Institute of Electrostatics Japan. 35, 108-113 (2011).

11. Fabian, P., McDevitt, J. J., Houseman, E. A., and Milton, D. K. Airborne influenza virus detection with four aerosol samplers using molecular and infectivity assays: considerations for a new infectious virus aerosol sampler. Indoor air. 19, 433-441 (2009).

12. Mizuno, A. Electrostatic precipitation. IEEE Transactions on Dielectrics and Electrical Insulation. 7, 615-624 (2000).

13. Kim, H. R., An, S. and Hwang, J. High air flow-rate electrostatic sampler for the rapid monitoring of airborne coronavirus and influenza viruses. J Hazard Mater. 412, 125219 (2021). 
14. Roux, J.M., Kaspari, O., Heinrich, R., Hanschmann, N., and Grunow, R., Investigation of a New Electrostatic Sampler for Concentrating Biological and Non-Biological Aerosol Particles. Aerosol Science and Technology. 47, 463-471 (2013).

15. Ladhani, L., Pardon, G., Moons, P., Goossens, H., and Wijngaart, W. V. D. Electrostatic Sampling of Patient Breath for Pathogen Detection: A Pilot Study. Frontiers in Mechanical Engineering. 6, (2020).

16. Hong, S., Kim, M. W. and Jang, J. Physical collection and viability of airborne bacteria collected under electrostatic field with different sampling media and protocols towards rapid detection. Scientific Reports 11, 14598 (2021).

17. Kurita, H. et al. Single-molecule measurement of strand breaks on large DNA induced by atmospheric pressure plasma jet. Applied Physics Letters. 99, (2011).

18. Kurita, H. et al. Radical reaction in aqueous media injected by atmospheric pressure plasma jet and protective effect of antioxidant reagents evaluated by single-molecule DNA measurement. Japanese Journal of Applied Physics. 53, 05FR01 (2014).

19. Mizuno, A. and Yasuda, H. Damages of Biological Components in Bacteria and Bacteriophages Exposed to Atmospheric Non-thermal Plasma. Plasma for Bio-Decontamination, Medicine and Food Security. NATO Science for Peace and Security Series A: Chemistry and Biology, 79-92 (2012).

20. Tanaka, Y., Yasuda, H., Kurita, H., Takashima, K., and Mizuno, A., Analysis of the Inactivation Mechanism of Bacteriophage by Atmospheric Pressure Discharge Plasma. IEEE Transactions on Industry Applications. 50, 1397-1401 (2014).

21. Kisanuki, Y. et al. Corona Discharge with Bundle of Fine Conductive Fibers for Electrostatic Precipitation of Fine Smoke Particles. International Journal of Plasma Environmental Science and Technology. 13, 21-25 (2019).

22. O'Connell, K. P. et al., Real-Time Fluorogenic Reverse Transcription-PCR Assays for Detection of Bacteriophage MS2. Applied and Environmental Microbiology. 72, 478-483 (2006).

\section{Figures}




\section{- Corona discharge+Airflow - Airflow only —n.c.}

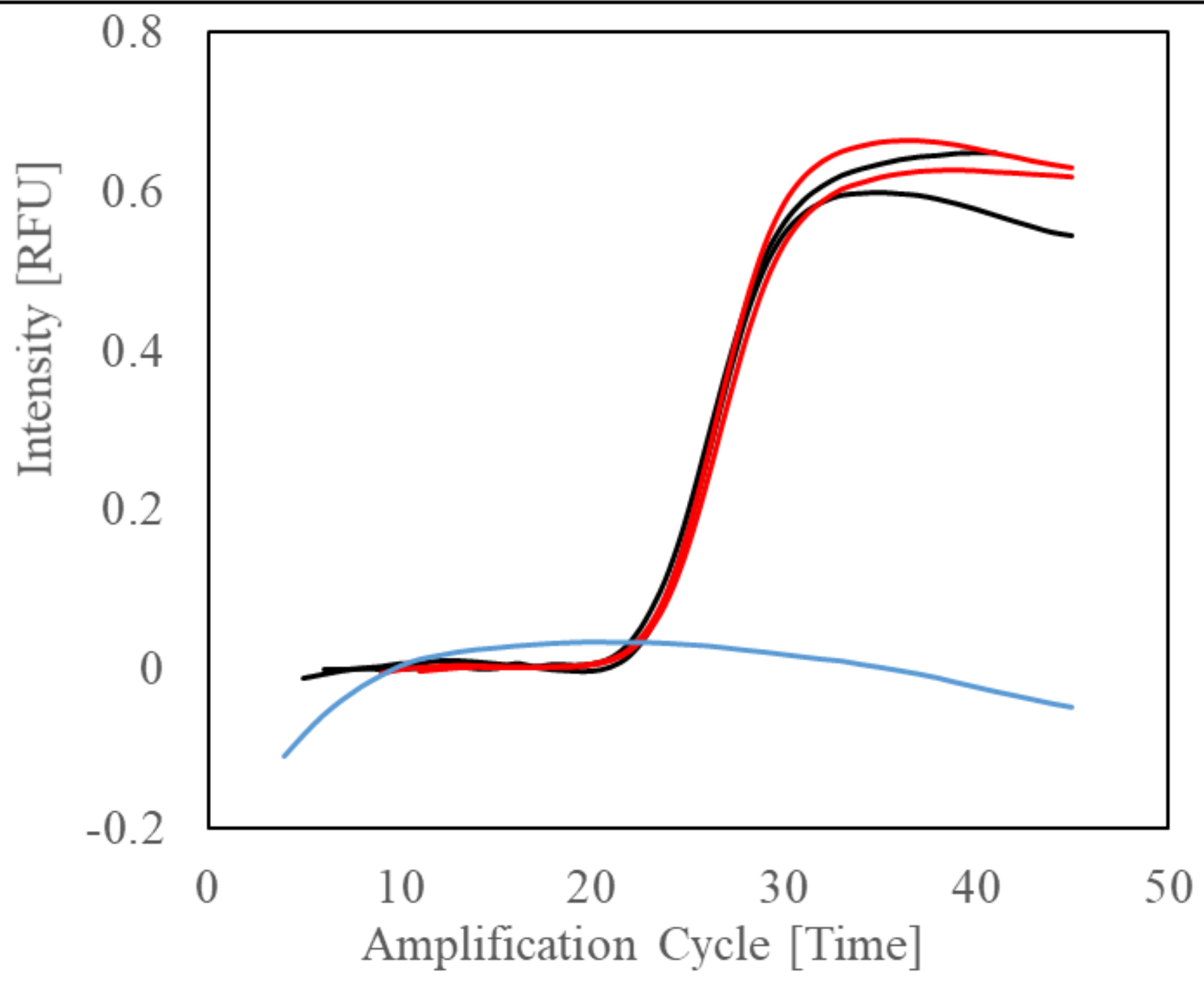

Figure 1

RT-qPCR analysis of the effect of exposure to corona discharge on bacteriophage MS2 RNA. 

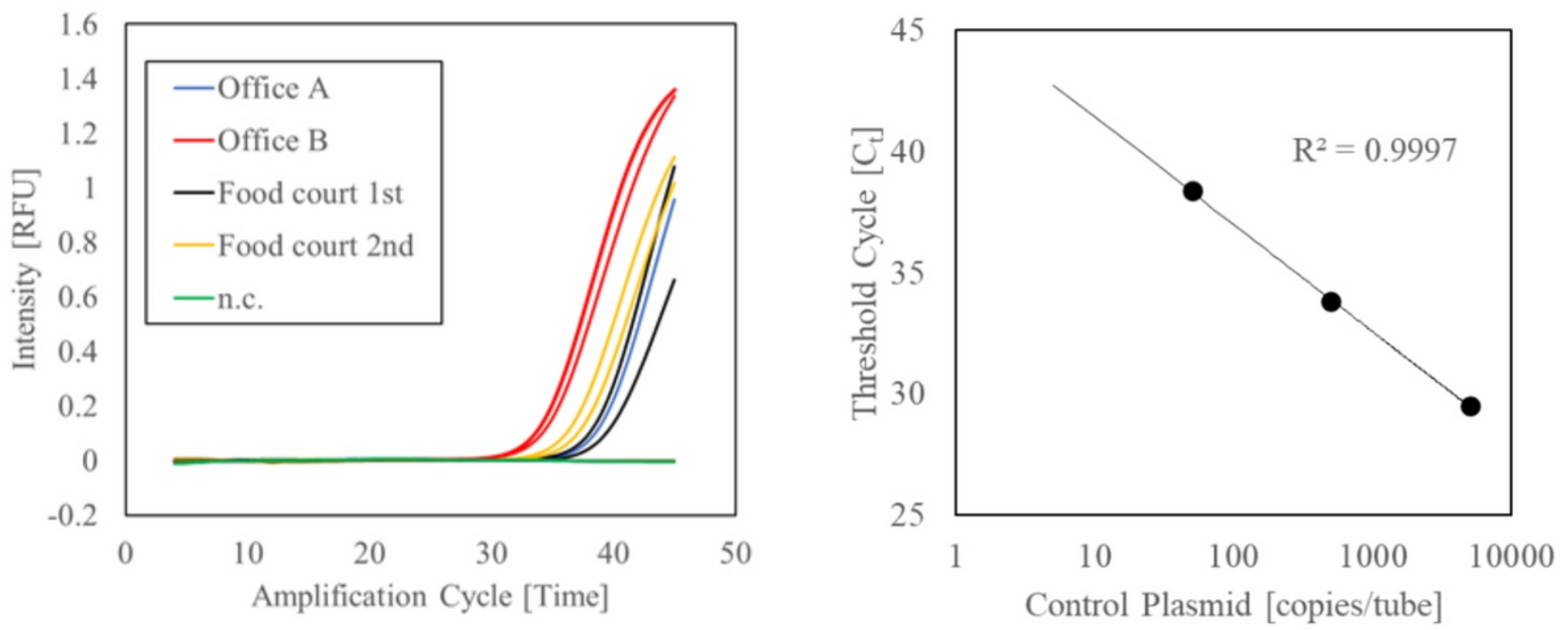

Figure 2

(a) Amplification curve of RT-qPCR for N2 region. Each sample was subjected to RT-qPCR twice. (b) Calibration curve of RT-qPCR using positive control step dilution series of N2 region.

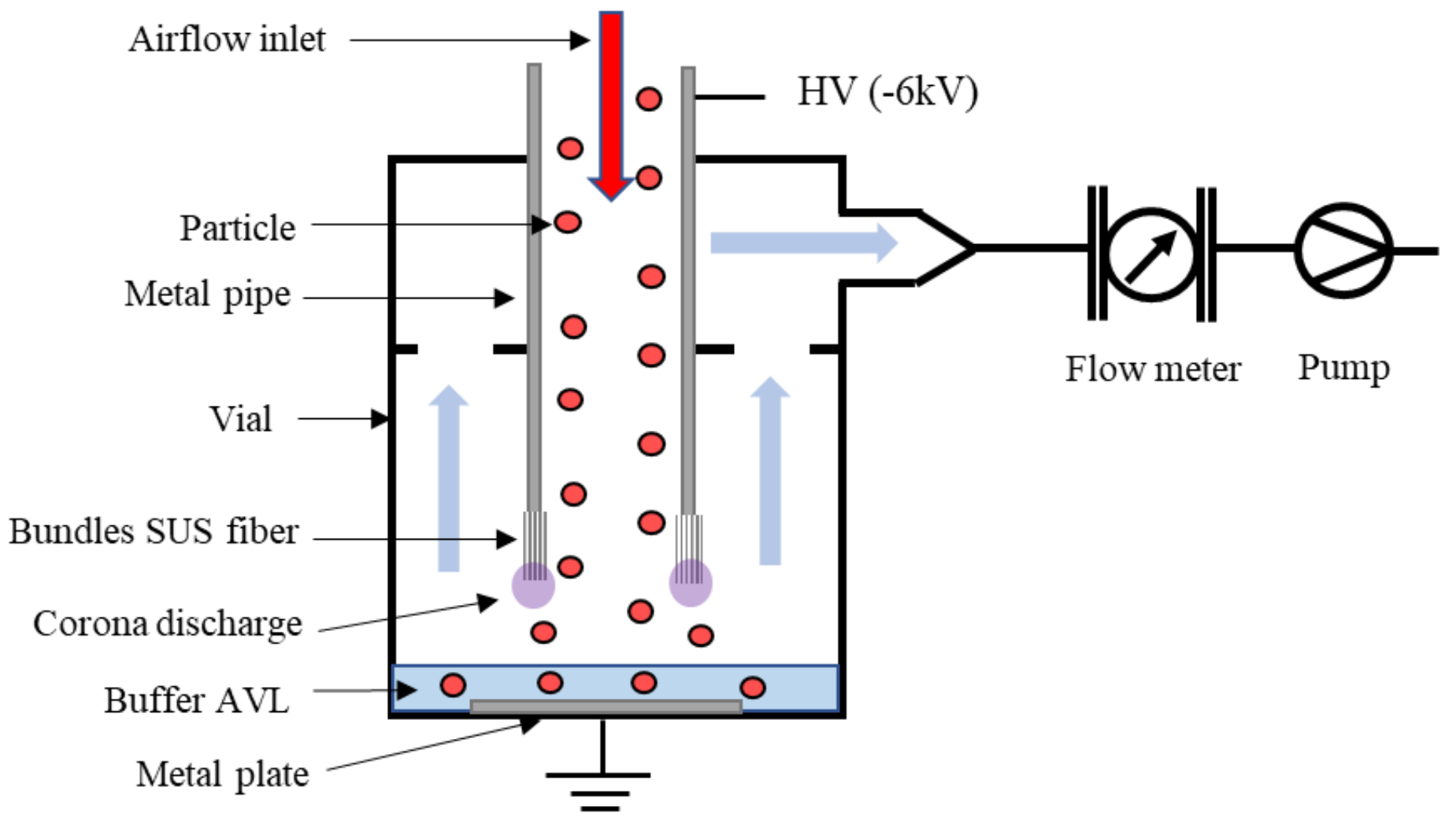

Figure 3

Schematic diagram of the electrostatic sampler. 